\title{
The ways ensuring energy balance in Uzbekistan
}

\author{
Otabek Akhmedov ${ }^{1}$, Otabek Begmullaev ${ }^{2 *}$ \\ ${ }^{1}$ Tashkent architecture and civil engineering institute, Tashkent, Uzbekistan, Tashkent, University St. 2A, 100095, Uzbekistan \\ ${ }^{2}$ Tashkent State Technical University named after Islam Karimov, Department of "Industrial economics and management" of the \\ Electrical Energy Faculty, Tashkent, University St. 2A, 100095, Uzbekistan
}

\begin{abstract}
The article deals with the problems of ensuring the energy balance in the Republic of Uzbekistan. The energy system of Uzbekistan is a vertically integrated structure, which is based on electricity source generation and distribution networks. The article considers the measures significant for the introduction of renewable energy sources in the energy balance of Uzbekistan. Data on the potential of renewable energy sources and alternative energy development of Uzbekistan is presented in the paper as well.
\end{abstract}

\section{Introduction}

One of the key tasks of the Anti-Crisis Program implemented in Uzbekistan is the modernization of the energy sector, reduction of the energy intensity of the gross domestic product (GDP) and introduction of an effective energy-saving system. The growth of the economy competitiveness and well-being of the population largely depends on the rational, scientificallygrounded level of electricity and energy resource use [14].

The fuel and energy sector plays a key role in the development of Uzbek economy: the investment in this sector is almost $50 \%$ that makes up $7 \%$ of the total gross domestic product (GDP) [5,6]. To date, measures are being taken to achieve an increase in the efficiency of power plant capacity use, a decrease in specific energy intensity and in the share of natural gas by increasing the use of coal in the process of energy production, based on modernization, technical and technological re-equipment of enterprises, the introduction of resource-saving technologies, and, as a result, ensuring a reliable and high-quality supply of electricity and heat to consumers for a long-term period [7-9]. At the same time, in the context of the globalization of the world economy, a reduction in the growth of non-renewable energy resources, increased competition for liquid hydrocarbons and solid fuels in the world markets, provision of a sustainable economic development, modernization of existing technologies, development and implementation of innovation technologies at the fuel and energy complex enterprises of the Republic, as well as development and expansive involvement of new sources of alternative energy to the country's energy balance are becoming extremely important. This problem is also actual for fuel and energy companies. Hence, there is a need for the development and implementation of an effective innovation policy at the enterprises of the fuel and energy complex of the Republic of Uzbekistan, the essential task of which is to create a system that will allow to use the intellectual, scientific and technical potential of the industry in production in the shortest period of time.

\section{Half-wave circuit}

The energy system of Uzbekistan, interconnected with the high-voltage transmission lines with neighboring republics of the CIS - Kazakhstan, Kyrgyzstan and Tajikistan, transmits electricity to Afghanistan. At present, the independent states strive for self-sufficiency of national energy companies, not always being guided by the overall efficiency of the Unified Energy System of Central Asia, which is managed by the Coordination Dispatch Center (CDC) "Energy" in Tashkent. The territorial distribution of the natural energy resources of the Central Asian republics is very uneven: in Kyrgyzstan and Tajikistan, the main hydropower resources are concentrated due to the construction of cascades of hydroelectric power plants on the tributaries of the Central Asian waterways - the Syrdarya and Amu Darya rivers [10-15]. The fuel resources that Uzbekistan and Kazakhstan have are experiencing a shortage of water for irrigating agricultural lands. The process of mutually beneficial exchange of energy and water resources between states often takes place with some certain difficulties.

Cross-border, interstate tariffs for the sale of electricity are set at the level of governments involved in international projects in the field of electricity. The tariff can be set through negotiations, but as a rule, it always equals or exceeds the transmission tariff on internal lines; it is also determined by the nature of the organization supplying and / or receiving electricity [16$23]$.

\footnotetext{
* Corresponding author: elyor.saitov@mail.ru
} 
In the Unified Energy System of Central Asia and other CIS networks, special fees are charged for frequency regulation, for unscheduled flows of electricity from one country to another, caused, for example, by an unexpected sharp increase in demand in a neighboring country. This issue is usually resolved separately with the help of one of the network operators [24-27].

A serious problem in the energy sector of Uzbekistan is a high deterioration percentage of power generating equipment - over $50 \%$ of fixed assets and, as a result, deterioration of the technical and economic indicators of operating power plants. Specific fuel consumption at TPPs is $380.8 \mathrm{~g} / \mathrm{kWh}$, which corresponds to an efficiency of $32.3 \%$, while $80 \%$ of the fuel consumed by thermal power plants is natural gas.

\section{Full waive circuit}

According to the experts, the share of hydrocarbons in the structure of the energy balance is approximately $86 \%$. It is planned to increase the share of other energy sources by 2030 , since the diversification of energy resources is the key to energy security in the long term. A number of documents have been adopted, focused on the development of nuclear energy and renewable energy sources. Now the Ministry of Energy and relevant departments have been instructed to develop an integrated national energy strategy by 2030. After its approval, Uzbekistan will have a clear program for achieving energy balance through the production of electricity in various ways.

An important role is assigned to work on the involvement of renewable energy sources in the energy balance of Uzbekistan: sun, wind, hydropower resources, geothermal waters. According to the Eco - Energy Research and Development Center of the State Committee for Nature Protection, Uzbekistan has significant potential for renewable energy sources (see Table 1).

\begin{tabular}{|c|c|c|c|c|c|}
\hline \multirow{2}{*}{ Potential } & \multirow{2}{*}{ Total } & \multicolumn{4}{|c|}{ Including by type of energy } \\
\cline { 3 - 6 } & & Hydropower & $\begin{array}{r}\text { Solar } \\
\text { power }\end{array}$ & $\begin{array}{c}\text { Wind } \\
\text { power }\end{array}$ & $\begin{array}{c}\text { Geothermal } \\
\text { power }\end{array}$ \\
\hline 1 & 2 & 3 & 4 & 5 & 6 \\
\hline Gross & 50984,6 & 9,2 & 50973 & 2,2 & 0,2 \\
\hline Technical & 179,0 & 3,2 & 176,8 & 0,4 & - \\
\hline Harnessed & 0,6 & 0,6 & 1 & - & - \\
\hline
\end{tabular}

Note. Gross potential is the theoretical amount of energy supplied or generated in a given area.

Technical potential is part of the gross potential that can be realistically used with existing technologies.

The main factors contributing to the accelerated development of renewable energy sources in the world are as follows:

- ensuring energy security;

- saving stocks of used energy resources for future generations;

- striving to preserve the environment and ensure environmental safety;
- solving social problems, improving the quality of life.

A few years ago, a situation with the electricity shortage in the regions of Uzbekistan was very acute. For the coming years, Uzbekistan has targeted achieving an energy balance, where both renewable energy sources and nuclear power plants occupy their niches.

\section{Conclusion}

It is assumed that by 2030 the share of renewable energy sources (solar, wind, and hydroelectric power plants) in energy production will have been about $30 \%$. By 2030, it is planned to double the current hydroelectric capacity from $1.9 \mathrm{GW}$ to $3.8 \mathrm{GW}$, and industrial-scale solar and wind power plants with a capacity of $5 \mathrm{GW}$ and $3 \mathrm{GW}$, respectively, will have been built. The capacity of 2 power units of the NPP will have been $2.4 \mathrm{GW}$. It is expected that another $1 \mathrm{GW}$ of capacity will be supplemented by means of small solar photovoltaic stations installed by population. Thus, it is obvious that RES and nuclear energy do not contradict, but, on the contrary, complement each other.

According to the experts, it is impossible to single out one type of energy development as a priority today: it is necessary to combine traditional energy sources with several types of renewable energy. Given the current rate of economic growth, the state economy will need more and more electricity. And the solution may just be the development of new sources of electricity generation, such as renewable energy sources and nuclear energy.

\section{References}

1. National report on the Republic of Uzbekistan / D. Abdusalamov; Comp. within the framework of the UN Economic Commission for Europe project "Increasing the energy effect of the national programs of the CIS member states on energy efficiency and energy saving to improve their energy security." - Tashkent: SJSC "Uzbekenergo", 2013.

2. Allaeva G.Zh. Energy saving as a factor in increasing efficiency in the implementation of innovative technologies at the enterprises of the fuel and energy complex // Problems of energy and resource saving. - 2014. - ${ }^{14}$. - S. 212-215.

3. O.I.Begmullaev. Assessment of the financial and economic condition of an industrial enterprise. Questions of economic sciences, no. 5, art. 25-26, 2008.

4. O.I.Begmullaev. Factors of economic insolvency of industrial enterprises and the efficiency of their functioning in market conditions - EURASIAN SCIENTIFIC, art. 165, 2017.

5. M.K.Bakhadyrkhanov, S.A.Valiev, N.F.Zikrillaev, S.V.Koveshnikov, E.B.Saitov, S.A.Tachilin. Silicon photovoltaic cells with clusters of nickel atoms. Applied solar energy 52 (4), pp.278-281, 2016. 
6. Javoxir Toshov., Elyor Saitov. Portable autonomous solar power plant for individual use. E3S Web of Conferences 139 01087. 2019.

7. I.Sapaev, E.Saitov, N.Zoxidov and B.Kamanov. Matlab-model of a solar photovoltaic station integrated with a local electrical network. Conmechydro - 2020 IOP Conf. Series: Materials Science and Engineering 883(2020) 012116.

8. Shoguchkarov S.Q., Jamolov T.R., Mukhtarov N.Y., Yuldoshev I.A. Study of the Operating Parameters of a Wind Power Plant with 0,75 MW Power under the Conditions of Tashkent Oblast Applied Solar Energy.2018. Vol.54, pp. 392-394.

9. M.K.Bakhadyrkhanov., S.A.Valiev., N.F.Zikrillaev., S.V.Koveshnikov., E.B.Saitov., S.A.Tachilin. Silicon-based solar cells with clusters of nickel atoms // Geliotekhnika No. 4 pp. 28-32, 2016.

10.E.B.Saitov. Study of Quantitative and Qualitative Characteristics of Nickel Clusters and Semiconductor Structures. Journal of Materials Science and Chemical Engineering. №4 y. 2016, pp. 30-35.

11. Abdurakhmanov B.A., Bakhadirkhanov M.K., Ayupov K.S., Iliyev H.M., Mavlyanov A., Saitov E.B., Kamalov H.U. Formation of Clusters of Impurity Atoms of Nickel in Silicon and Controlling Their Parameters. Nanoscience and Nanotechnology, Vol. 4, No. 2, 2014. pp. 23-26.

12. Zikrillaev N.F., Saitov E.B. Silicon-based photocells with Schottky micro-barriers. Bulletin of the Turin Polytechnic University; 2014.S. 31-33.

13. Saitov E.B. Study of silicon photocells with Si-Ge microheterostructures. Special issue // Bulletin of Tashkent State Technical University, 2015, pp. 6671.

14. Iliev Kh.M., Saitov E.B., Saydaliev S.Kh., Tachilin S.A. Portable autonomous solar power plant for individual use. Problems of energy and resource conservation. Tashkent State Technical University, 2014, No. 1-2. from. 183-185.

15. Zikrillaev N.F., Saitov E.B., Tukhtasinov M.M. Lowtemperature diffusion of Ge, S, Ni and Mn impurities in silicon to obtain photocells. Bulletin of the Turin Polytechnic University, 2014. p. 34-39.

16. Zikrillaev N.F., Saitov E.B., Tachilin S.A. Efficient inverters for alternative energy sources. International scientific-practical conference "Problems of modern mechanical engineering". Andijan May 16-17, 2013. S.16-18

17. Bakhadyrkhanov M.K. Abdurakhmonov B.A., Saitov E.B. Study of the current-voltage characteristics of the microstructure of clusters of nickel-silicon atoms. Academy of Sciences of the Republic of Uzbekistan. Fundamental and applied questions of physics. Trudy International Conference dedicated to the 70th anniversary of Physicist Technician Institute NPO "Physics-Sontsa" :. November 14 - 15, 2013 Tashkent, p. 107-108.
18. M.K.Bakhadyrkhanov, S.A.Valiev, N.F.Zikrillaev, S.V.Koveshnikov, E.B.Saitov., S. A.Tachilin. Silicon Photovoltaic Cells with Clusters of Nickel Atoms. Applied Solar Energy, 2016, Vol. 52, No. 4, pp. 278281.

19. B.A.Abdurakhmanov, M.K.Bakhadirkhanov, H.M.Iliyev, S.B.Isamov, A.Mavlyanov, E.B.Saitov, H.U.Kamalov, Z.Saparniyazova, O.Sattarov, U.Kh.Sodikov, N.F.Zikrillayev. Silicon with Clusters of Impurity Atoms as a Novel Material for Photovoltaics. Nanoscience and Nanotechnology 2014, 4(3): 41-43.

20. Javoxir Toshov., Elyor Saitov. Portable autonomous solar power plant for individual use. E3S Web of Conferences 139 01087. 2019.

21. E.B.Saitov. Technology of manufacturing solar cells with clusters of $\mathrm{Ni}$ atoms. Asian journal of multidimensional research impact factor, ISSN: 2278-4853 Vol 8, Issue 3, March $2019=6.053$, pp. 494-499.

22. Zikrillayev Nurilla, Saitov Elyor, Botirov Bozorbek, Nasirdinov Bakhodirw, Kurbanov Yunus, Turayev Farxodjon, Shodiyeva Nozina. Study of the results of diffusion doping technique for producing heterostructures ( $\mathrm{Si}-\mathrm{Ge})$ using microprobe analysis. Austrian Journal of Technical and Natural Sciences. «East West» Association for Advanced Studies and Higher Education GmbH. No.1-2. pp.56-61, 2019.

23. I.Sapaev, E.Saitov, N.Zoxidov and B.Kamanov. Matlab-model of a solar photovoltaic station integrated with a local electrical network. Conmechydro - 2020 IOP Conf. Series: Materials Science and Engineering 883(2020) 012116.

24. Saitov E.B, Toshov J.B, Umarov Sh.B., Fayzullayev B.H., Abdullabekov I.A, NasriddinovB.A. Optimization of Solar Power Systems in Different Regions. Journal of critical reviews, ISSN - 23945125VOL 7, ISSUE 15, 2020.

25. Saitov Elyor Bakhriddinovich, Pulatov Abror Obidovich. Development of an Experiment Control System at a Laboratory Installation of a Photovoltaic Station in a Remote access Mode Based on Web Technologies. Journal of critical reviews, ISSN 2394-5125 VOL 7, ISSUE 15, 2020.

26. Zikrillayev Nurullo, Saitov Elyor. Silicon materials the future of photovoltaics. Monograph - LAP LAMBERT Academic Publishing. 2019, ISBN: 987620-0-50311-4.

27. Javoxir Toshov., Elyor Saitov. Portable autonomous solar power plant for individual use. E3S Web of Conferences 139 01087. 2019. 